\title{
Rhipicephalus sanguineus (Acari: Ixodidae), the brown dog tick, parasitizing humans in Brazil
}

\author{
Rhipicephalus sanguineus (Acari: Ixodidae), o carrapato \\ vermelho do cão, parasitando humanos no Brasil
}

\author{
Filipe Dantas-Torres ${ }^{1}$, Luciana Aguiar Figueredo ${ }^{2}$ \\ and Sinval Pinto Brandão-Filho ${ }^{1}$
}

\begin{abstract}
The objective of this paper is to describe four cases of human parasitism by Rhipicephalus sanguineus (Latrielle) in Brazil. During an investigation regarding the species of ectoparasites of domestic dogs from the metropolitan region of Recife, Pernambuco state, four dog owners were found to be parasitized by ticks. The ticks were collected from these individuals and their dogs. All the ticks were identified as Rhipicephalus sanguineus. These are, to our knowledge, the first four cases of human parasitism by this tick species in Brazil. The possible implications of this finding are discussed here.
\end{abstract}

Key-words: Brown dog tick. Human parasitism. Tick-borne diseases. Epidemiology.

\section{RESUMO}

0 objetivo deste artigo é descrever quatro casos de parasitismo humano por Rhipicephalus sanguineus (Latrielle) no Brasil. Durante uma investigação sobre as espécies de ectoparasitas de cães domésticos provenientes da Região Metropolitana de Recife, Pernambuco, quatro proprietários de cães foram encontrados parasitados por carrapatos. Foram coletados carrapatos dos indivíduos e de seus cães. Todos os carrapatos foram identificados como Rhipicephalus sanguineus, sendo, portanto, descritos os primeiros quatro casos de parasitismo humano por esta espécie de carrapato, no Brasil. Neste trabalho, são discutidas as possíveis implicações epidemiológicas deste achado.

Palavras-chaves: Carrapato vermelho do cão. Parasitismo humano. Doenças transmitidas por carrapatos. Epidemiologia.

The relationship between man and dog has been established for thousand of years ${ }^{35}$. Due to this old and close relationship, eventually, some ectoparasites of domestic dogs may be seen parasitizing man. This parasitism, though unusual, might be responsible for a simple skin lesion or for the transmission of infectious agents.

Rhipicephalus sanguineus (Latreille), commonly called the brown dog tick or kennel tick, is one of the most widely distributed of all ticks ${ }^{14}$. This tick was introduced from the Afrotropical Region to many countries in the world, probably by the importation of infested domestic dogs, its preferred host ${ }^{15}$. For dogs, the brown dog tick can produces debilitating effects due to both blood loss and the transmission of infectious agents ${ }^{34}$.
In Brazil, $R$. sanguineus is usually found on dogs from both urban and rural environments. Additionally, there are reports of $R$. sanguineus parasitizing other animals, such as rabbits, cats $^{23}$, the Norway rat ${ }^{38}$, pigeons ${ }^{13}$, and wild canids ${ }^{23}$.

The brown dog tick is an ectoparasite of public health interes $^{29}$, due its capacity to carry and transmit a number of pathogens to humans. Despite being unusual, there are a number of reports regarding human parasitism by $R$. sanguineus in the world ${ }^{571416202122283336}$. However, historically human parasitism by this tick species occurs occasionally in the Mediterranean region, Central America, and more rarely in the United States. In Europe, human parasitism by $R$. sanguineus is of particular importance because this tick is both the vector

\footnotetext{
1. Centro de Pesquisas Aggeu Magalhães da Fundação Oswaldo Cruz, Recife, PE, Brazil. 2. Universidade Federal Rural de Pernambuco, Recife, PE. Address to: Dr. Filipe Dantas-Torres. CPqAM/FIOCRUZ, Campus UFPE, Av Moraes Rego s/n, 50670-420 Recife, PE, Brazil.

Tel: 5581 2101-2562, Fax: $55813453-2449$

e-mail: fdt@cpqam.fiocruz.br

Recebido para publicação em 17/3/2005

Aceito em 24/11/2005
} 
and reservoir of Rickettsia conorii, the causative agent of boutonneuse fever (also known as Mediterranean spotted fever) ${ }^{37}$

Until last year, there was no record of human parasitism by R. sanguineus in Brazil23. However, at the beginning of 2005, we briefly reported the first description of human parasitism by this species of ixodid tick ${ }^{11}$. The aim of this paper is to further describe the three cases reported previously ${ }^{11}$ as well as to record a new case of human parasitism by $R$. sanguineus. Additionally, the possible burden to public health of this occurrence in Brazil is discussed.

\section{MATERIAL AND METHODS}

Study area. The investigation was carried out in three houses located in two municipalities of the metropolitan region of Recife, Pernambuco State, Northeastern Brazil (Figure 1). According to Köppen's classification, this region has a tropical climate with the rains concentrated from autumn to winter (February to June). The annual average temperature is $25.8^{\circ} \mathrm{C}$, varying from 24 to $26^{\circ} \mathrm{C}$, while the relative humidity varies from 72.5 to $85 \%$, and the annual pluviometer index is over 1,600 millimeters ${ }^{1}$.

Tick collection. During a previous investigation regarding the ectoparasites of domestic dogs from the metropolitan region of Recife $\mathrm{e}^{12}$, three dog owners were found to be parasitized by ticks. Hence, we manually collected the ticks encountered on these subjects and also on their dogs. A few months later, another dog owner complained that she had found a tick attached to her body and sent us the specimen for identification. All the ticks collected were preserved in $70 \%$ ethanol.

Identification of collected ticks. Identification was realized under a stereomicroscope, 100x magnification, by comparison with characteristics presented in the taxonomic key ${ }^{2348}$. Two of the collected specimens examined here were deposited in the Entomological Collection of Instituto Oswaldo Cruz, Rio de Janeiro, $\mathrm{RJ}$, Brazil. The others remain deposited in the personal collection of the first author of this paper (F.D.T.).

\section{RESULTS AND DISCUSSION}

Both tick and subject data are shown in Table 1. All the individuals found the ticks attached in their inferior limbs during the summer (December to March). All the ticks examined were identified as $R$. sanguineus. The tick/person ratio documented in the present study was 1:1, as reported in Argentina where only a single adult male $R$. sanguineus was found on a girl from the city of Salta ${ }^{21}$.

Table 1 - Human parasitism by Rhipicephalus sanguineus in Pernambuco, Brazil.

\begin{tabular}{lccccccc}
\hline \multicolumn{3}{c}{ Subject data } & & \multicolumn{4}{c}{ Tick data } \\
\cline { 1 - 2 } \cline { 5 - 7 } Age & Sex & Job & & $\mathrm{n}$ & Collected in & Collected by & Stage \\
\hline 24 & male & veterinarian & & 1 & Olinda & F.D.T. & adult male \\
22 & female & student & & 1 & Olinda & F.D.T. & adult male \\
28 & female & dentist & & 1 & Olinda & $*$ & adult male \\
24 & female & veterinarian & & 1 & Recife & F.D.T. & adult male \\
\hline
\end{tabular}

*Collected by the subject.

FD.T.: Filipe Dantas-Torres

It is interesting to note that in our study only adult male ticks were encountered parasitizing humans. In Europe, adult brown dog ticks parasitize lager animals, like dogs, wild carnivores, ungulates and man, while the immature stages feed on rodents, hedgehogs and other small mammals ${ }^{14}$. In contrast, some authors reported that the immature stages of $R$. sanguineus are most commonly involved in human parasitism ${ }^{192232}$. This aspect is important due to the fact that the $R$. sanguineus nymphs are considered to be the main transmitters of Rickettsia conori ${ }^{31}$. The immature stages are easily overlooked because of their small size ${ }^{22}$. Hence, it is generally believed that this tick feeds on humans more than previously recognized.

In Europe, most of the cases of boutonneuse fever are registered during the summer, when the tick vectors are highly active $^{30}$. Similarly, it was demonstrated that in United States human parasitism by the brown dog tick occurs predominantly during the summer and fall ${ }^{70}$. Unfortunately, little is known regarding the biology of this tick species under Brazilian natural conditions. Indeed, studies on this subject are crucial for a better understanding of the tick-human interactions in our area.

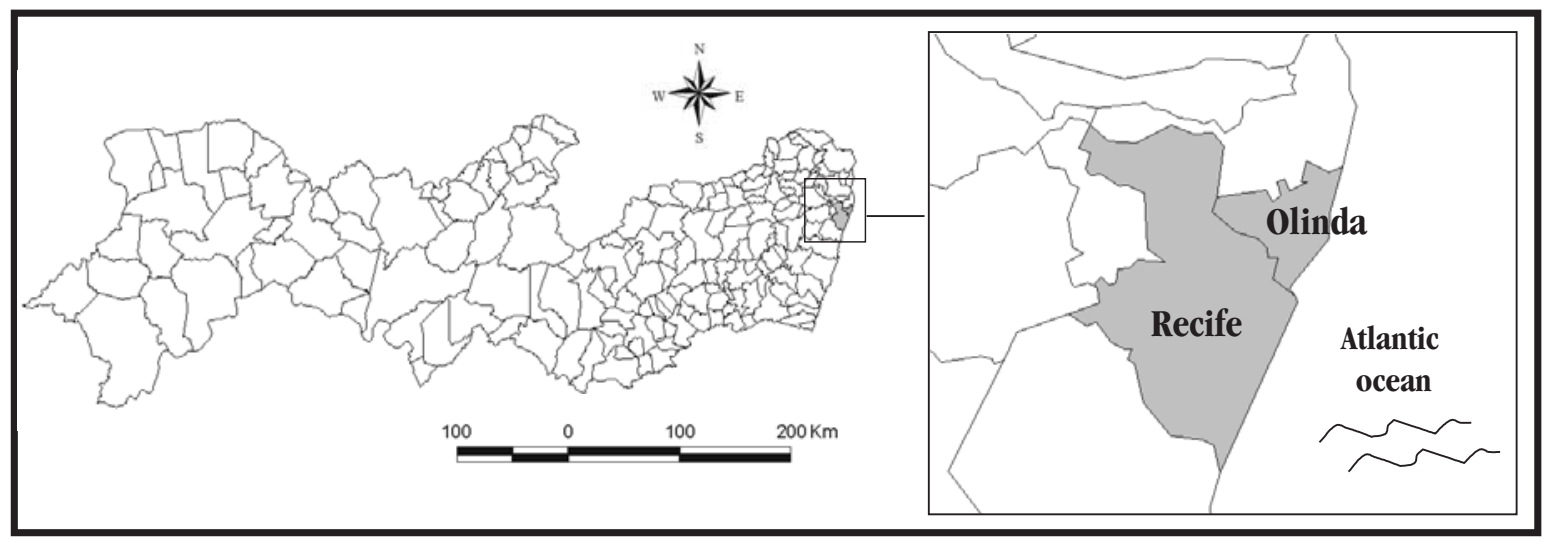

Figure 1 - Location of the two municipalities in the metropolitan region of Recife, Pernambuco, Brazil. 
Dog parasitism by $R$. sanguineus is usually found in all Brazilian states $^{2} 412151723$. Although this tick has already been found parasitizing other animals in this country 3132338 , which now include man, the domestic dog is definitely its preferred host. In the State of Pernambuco there are few researchers dedicated to studying ectoparasite species of either domestic or wild animals. However, it is already known that $R$. sanguineus is the most prevalent ectoparasite of dogs from the metropolitan region of Recife ${ }^{12}$, where the four cases presented here are from. Additionally, pathogen microorganisms, e.g., Ehrlichia canis, Babesia canis, and Anaplasma platys, usually infect the domestic dogs of this region ${ }^{10}$.

During the present investigation, as expected for a nidicolous tick ${ }^{23}$, several ticks were seen in the house, mainly on the sofa (Figure 2) and on the walls.

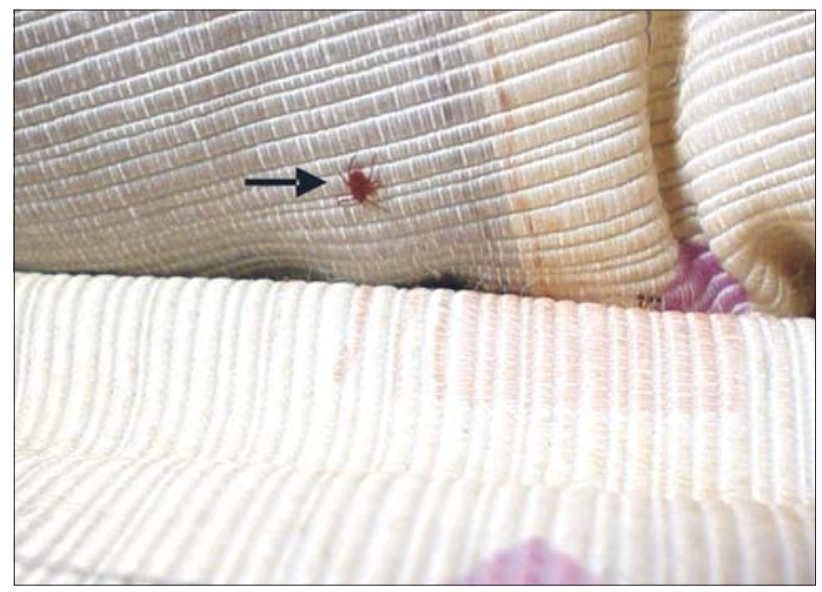

Figure 2 - A male Rhipicephalus sanguineus (arrow) found on the sofa of the residence of the case from Recife.

Our hypothesis is that any person who lives in an environment with highly parasitizing dogs (Figure 3) might be included in the group at risk for parasitism by $R$. sanguineus. Veterinarians are also included in this group, because they come into contact with infested dogs during their daily routine in endemic areas.

Tick-borne diseases are recognized as an emerging public health problem in many countries ${ }^{30}$ and $R$. sanguineus has been linked to some of these diseases, such as boutonneuse fever. It

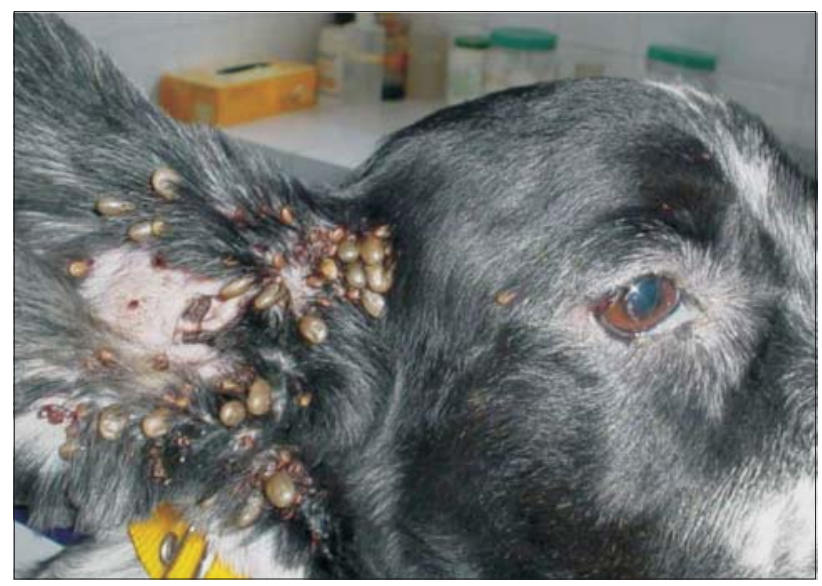

Figure 3 - A female adult dog highly parasitized by R. sanguineus. is also known that $R$. sanguineus found on dogs from regions where Rickettsia rickettsii infection is endemic might be infected with spotted fever group rickettsiae $\mathrm{e}^{2434}$. Thus, the present results, associated with the previous reports of cases of tick-borne rickettsial disease in Brazil ${ }^{6} 26{ }^{32}$, might highlight a new epidemiological situation for tick-borne diseases in this country.

It is well known that the role of $R$. sanguineus as a vector of the causative agent of canine ehrlichiosis and other infectious organisms to man might be underestimated ${ }^{7}$. Nevertheless, there is recent evidence indicating the role of this tick in the epidemiology of canine visceral leishmaniasis ${ }^{9}$. Consequently, there is an urgent need for further investigations with the aim of improving current understanding of the epidemiology of tickborne diseases in Brazil, with emphasis on the possible vectors, reservoir hosts, causative agents and groups at risk. Similary, studying the ecology and biology of $R$. sanguineus anthropophilic strains in our area will be a crucial step in the adoption of future control measures focused on this tick.

The presence of $R$. sanguineus in different hosts in Brazil demonstrates its eclectic feeding behavior and certainly reinforces the possibility of previous unreported cases of human parasitism by this species of tick in this country. In fact, the tick species usually involved in the human parasitism in Brazil are already known ${ }^{152627}$. However, both unusual and unreported tick-human interactions might be less uncommon than we think.

\section{ACKNOWLEDGEMENTS}

We wish express our thanks to the two anonymous referees for their helpful comments on the submitted version of this paper.

\section{REFERENCES}

1. Andrade MCO. Atlas escolar de Pernambuco. Grafset, João Pessoa, 2003.

2. Aragão H. Notas sobre ixódidas brazileiros. Memórias do Instituto Oswaldo Cruz 3:145-195, 1911.

3. Aragão H. Ixodidas brasileiros e de alguns paizes limitrophes. Memórias do Instituto Oswaldo Cruz 31:759-843, 1936.

4. Aragão H, Fonseca F. Notas de Ixodologia VIII. Lista e chave para representantes da fauna Ixodológica Brasileira. Memórias do Instituto Oswaldo Cruz 59:115-129, 1961.

5. Burgdorfer W, Adkins Jr TR, Priester LE. Rocky Mountain spotted fever (tick-borne typhus) in South Carolina: an educational program and tick/ rickettsial survey in 1973 and 1974. American Journal Tropical Medicine and Hygiene 24:866-872, 1975.

6. Calic SB, Galvão MA, Bacellar F, Rocha MC, Mafra CL, Leite RC, Walker DH. Human ehrlichioses in Brazil: first suspect cases. Brazilian Journal of Infectious Diseases 8:259-262, 2004.

7. Carpenter TL, McMeans MC, McHugh CP. Additional instances of human parasitism by the brown dog tick (Acari: Ixodidae). Journal of Medical Entomology 27:1065-1066, 1990.

8. Cooley RA. The genera Boophilus, Rhipicephalus, and Haemaphysalis (Ixodidae) of the New World. Government Printing Office, Washington, 1946.

9. Coutinho MTZ, Bueno LL, Sterzik A, Fujiwara RT, Botelho JR, Maria M, Genaro 0, Linardi PM. Participation of Rhipicephalus sanguineus (Acari: Ixodidae) in the epidemiology of canine visceral leishmaniasis. Veterinary Parasitology 128:149-155, 2005. 
10. Dantas-Torres F, Faustino MAG, Alves LC. Co-infection by Anaplasma platys, Babesia canis and Ehrlichia canis in a dog from Recife, Pernambuco, Brazil: case report. Revista Brasileira de Parasitologia Veterinária 13 (supl I): 371-371, 2004.

11. Dantas-Torres F, Figueredo LA, Brandão-Filho SP. Primeira descrição de parasitismo humano por Rhipicephalus sanguineus (Acari: Ixodidae) no Brasil. Revista da Sociedade Brasileira de Medicina Tropical 38 (supl I): 411-412, 2005.

12. Dantas-Torres F, Figueredo LA, Faustino MA. Ectoparasitos de cães provenientes de alguns municípios da Região Metropolitana do Recife, Pernambuco, Brasil. Revista Brasileira de Parasitologia Veterinária 13:151$154,2004$.

13. Diogo AAR, Guerim L, Pires JR, Couto ALG, Serra-Freire NM. Parasitismo por Rhipicephalus sanguineus Latreille, 1806 em Columbia livia Linnaeus na Cidade do Rio de Janeiro, Brasil. Entomologia y Vectores 10:277-280, 2003.

14. Estrada-Peña A, Jongejan F. Ticks feeding on humans: a review of records on human-biting Ixodoidea with special reference to pathogen transmission. Experimental and Applied Acarology 23:685-715, 1999

15. Evans DE, Martins JR, Guglielmone AA. A review of the ticks (Acari, Ixodida) of Brazil, their hosts and geographic distribution - 1. The state of Rio Grande do Sul, Southern Brazil. Memórias do Instituto Oswaldo Cruz 95:453-470, 2000

16. Felz MW, Durden LA, Oliver Jr JH. Ticks parasitizing humans in Georgia and South Carolina. Journal of Parasitology 82:505-508, 1996.

17. Figueiredo LTM, Badra SJ, Pereira LE, Szabó MPJ. Report on ticks collected in the Southeast and Mid-West regions of Brazil: analyzing the potential transmission of tick-borne pathogens to man. Revista da Sociedade Brasileira de Medicina Tropical 32:613-619, 1999.

18. Ghorbel A. Human ehrlichiosis, a new zoonosis. Archives du Institute Pasteur de Tunisia 67:11-24, 1990.

19. Gilot B, Laforge ML, Pichot J, Raoult D. Relationships between the Rhipicephalus sanguineus complex ecology and Mediterranean spotted fever epidemiology in France. European Journal of Epidemiology 6:357362, 1990

20. Goddard J. Focus of human parasitism by the brown dog tick, Rhipicephalus sanguineus (Acari: Ixodidae). Journal of Medical Entomology 26:628-629, 1989

21. Guglielmone AA, Mangold AJ, Vinabal AE. Ticks (Ixodidae) parasitizing humans in four provinces of north-western Argentina. Annals of Tropical Medicine and Parasitology 85:539-542, 1991.

22. Harrison BA, Engber BR, Apperson CS. Ticks (Acari: Ixodida) uncommonly found biting humans in North Carolina. Journal of Vector Ecology 22:6-12, 1997.

23. Labruna MB. Biologia-ecologia de Rhipicephalus sanguineus (Acari: Ixodidae). Revista Brasileira de Parasitologia Veterinária 13 (supl I): 123$124,2004$.
24. Lange JV, el Dessouky AG, Manor E, Merdan AI, Azad AF. Spotted fever rickettsiae in ticks from the northern Sinai Governate, Egypt. American Journal of Tropical Medicine and Hygiene 46:546-551, 1992.

25. Lemos ERS, Machado RD, Coura JR, Guimarães MAA, Freire NMS, Amorim M, Gazeta GS. Epidemiological aspects of the Brazilian Spotted Fever: seasonal activity of ticks collected in an endemic area in São Paulo, Brazil. Revista da Sociedade Brasileira de Medicina Tropical 30:181-185, 1997.

26. Lemos ERS, Machado RD, Pires FD, Machado SL, Costa LM, Coura JR. Rickettsiae-infected ticks in an endemic area of spotted fever in the State of Minas Gerais, Brazil. Memórias do Instituto Oswaldo Cruz 92:477-481, 1997.

27. Lima VL, Figueiredo AC, Pignatti MG, Modolo M. Spotted fever in the town of Pedreira, São Paulo State, Brazil. The relationship between the occurrence of cases and human parasitism by ixodid ticks. Revista da Sociedade Brasileira de Medicina Tropical 28:135-137, 1995.

28. Manfredi MT, Dini V, Piacenza S, Genchi C. Tick species parasitizing people in an area endemic for tick-borne diseases in north-western Italy. Parassitologia 41:555-560, 1990.

29. Palmas C, Bortoletti G, Conchedda M, Contini C, Gabriele F, Ecca AR. Study on immunobiology in ectoparasites of public health interest: Rhipicephalus sanguineus. Parassitologia 43:29-35, 2001.

30. Parola P. Tick-borne rickettsial diseases: emerging risks in Europe. Comparative Immunology, Microbiology and Infectious Diseases 27:297304, 2004.

31. Raoult D, Roux V. Rickettsioses as paradigms of new or emerging infectious diseases. Clinical Microbiology Reviews 10:649-719, 1997.

32. Rozental T, Bustamante MC, Amorim M, Serra-Freire NM, Lemos ER. Evidence of spotted fever group rickettsiae in state of Rio de Janeiro, Brazil. Revista do Instituto de Medicina Tropical de São Paulo 44:155-158, 2002.

33. Schenone H. Diagnósticos hechos a 1.384 pacientes que consultaron por probable mordedura de arañas o picaduras de insectos. Boletim Chileno de Parasitologia 51:20-27, 1996.

34. Sexton DJ, Burgdorfer W, Thomas L, Norment BR. Rocky Mountain spotted fever in Mississippi: survey for spotted fever antibodies in dogs and for spotted fever group rickettsiae in dog ticks. American Journal of Epidemiology 103:192-197, 1976.

35. Valla EFF. Two new dogs, and other Natufian dogs, from the Southern Levant. Journal of Archeological Science 24:65-95, 1997.

36. Venzal JM, Guglielmone AA, Estrada-Peña A, Cabrera PA, Castro 0. Ticks (Ixodida: Ixodidae) parasitising humans in Uruguay. Annals of Tropical Medicine and Parasitology 97:769-772, 2003.

37. World Health Organization. The vector-borne human infections of Europe: their distribution and burden in public health. WHO, Geneva, 2004.

38. Yoshizawa MAC, Souza JL, Bredt A, Baggio D. Ectoparásitos de Rattus norvergicus no Distrito Federal, Brasil. Revista Brasileira de Parasitologia Veterinária 5:39-42, 1996 